\section{Pro prikker}

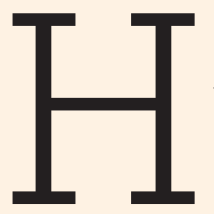

et is weer tijd voor de jaarlijkse griepprik! Bij deze roep ik iedere verpleegkundige op om die te gaan halen. Met deze uitspraak begeef ik mij op glad ijs, ik weet het. Want was het maar zo simpel. Veel verpleegkundigen geloven namelijk niet (meer) in de effectiviteit van de griepprik. En wie ben ik om dat te veroordelen?

Ik ben pro vaccinatie. Altijd al geweest. Als ik mij zou kunnen vaccineren tegen een verkoudheid, zou ik het nog doen. Ik prijs me gelukkig te leven in een land waarin we de welvaart en dus ook de middelen hebben om ons optimaal te beschermen tegen van alles en nog wat. En daar maak ik gretig gebruik van. In mijn leven staat veiligheid boven alles. In de auto draag ik een gordel en mijn huis is beveiligd tegen inbrekers. En ja, ik laat mij vaccineren tegen de griep. Schijnveiligheid? Misschien. Maar ik voel mij daar goed bij. Een ander zou het overdreven kunnen vinden. En dat mag. Uiteraard mag je ook weigeren om die prik te halen. Want wat zouden redenen zijn om je niet te laten vaccineren? Veel mensen denken dat je griep krijgt van het vaccin, of dat er stoffen in zitten die je ziek kunnen maken, of dat er toch altijd een ander virus rondwaart dan waar het vaccin voor is gemaakt. Anderen geloven zelfs in een vooropgezet plan van de farmaceuten, om flink geld te verdienen.

Reden genoeg om de ins en outs van die griepprik eens grondig te onderzoe- ken. Want als gerenommeerd vakblad achten wij het onze plicht je zo goed mogelijk te informeren. En dan is de keus aan jou.

Het is een kritisch artikel geworden. En wat blijkt? Bij gezonde volwassenen ligt de effectiviteit van het griepvaccin rond de $60 \%$, mits het vaccin matcht met het rondwarende virus. Bij een mismatch is de effectiviteit gemiddeld $44 \%$. Voor mij voldoende om de prik te halen. Voor een ander is een effectiviteit van $100 \%$ wellicht een voorwaarde. Maar dat vind ik niet realistisch. Marc van Ranst, hoogleraar virologie, epidemiologie en bio-informatica aan de Katholieke Universiteit Leuven, vergelijkt het met een autogordel. Wist je bijvoorbeeld dat de effectiviteit daarvan slechts $40 \%$ is? Serieus, ik stond er ook van te kijken. Het dragen van een autogordel is goddank verplicht... Moeten we die griepprik dan ook maar gaan verplichten of gaat dat te ver? Als je altijd trouw een autogordel draagt en je krijgt nooit een ongeluk, waarom draag je ' $m$ dan? Het antwoord op deze vraag bepaalt voor een groot deel hoe je je eigen veiligheidsgrenzen stelt. Ik hoop gewoon dat iedere verpleegkundige zich laat vaccineren. Gewoon voor de zekerheid. En dat is mijns inziens, goed genoeg.

\section{Alexia Hageman}

\section{Hoofdredacteur Nursing}

Alexia.Hageman@bsl.nl

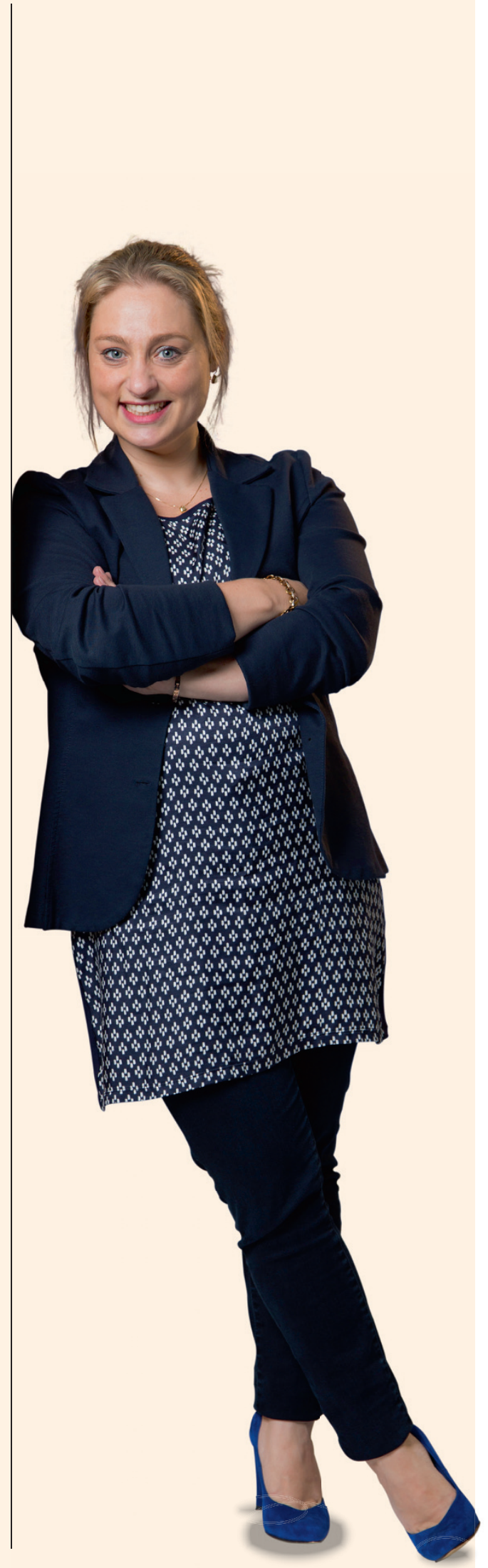

